\title{
IMPROVED SYNTHESIS OF [11C]METHYLAMINOBENZOVESAMICOL
}

\author{
G. Keith Mulholland* and Yong-Woon Jung \\ Division of Nuclear Medicine, University of Michigan Medical Center \\ 3480 Kresge III, Ann Arbor, Michigan, USA 48109-0552
}

\begin{abstract}
SUMMARY
An efficient two-step synthesis of the potential cholinergic neuronal mapping tracer [11C]methylaminobenzovesamicol (MABV) is described. A tert-butoxycarbonyl protecting group was used to activate the aniline nitrogen of aminobenzovesamicol toward [11 C]methyl iodide methylation under basic conditions. Following labeling, the protecting group was removed by brief acid treatment and the final product was purified by normal phase HPLC. The decay corrected yields of MABV are in the range of $30-70 \%$, based on ${ }^{11} \mathrm{CO}_{2}$, with a specific activity of $0.5-1.5 \mathrm{Ci} / \mu \mathrm{mol}$ and synthesis time of less than 45 minutes. This new route makes clinical scale doses of this interesting compound available for human positron emission tomography studies.
\end{abstract}

Key words: Vesamicol, Carbon-11, Radiolabeling, Cholinergic, PET.

\section{INTRODUCTION}

There is considerable interest in the drug vesamicol as a pharmacological tool for study of the vesicular acetylcholine uptake system (1-3). Radiolabeled analogs of vesamicol show potential for mapping cholinergic neuron densities in the central nervous system (4-6), and heart (7). A promising ${ }^{11} \mathrm{C}$-analog under study is methylaminobenzovesamicol, [ $\left.{ }^{11} \mathrm{C}\right] \mathrm{MABV},(-)-(2 R, 3 R)$-trans-5-(N-[11 C]methylamino)-2hydroxy-3-(4-phenylpiperidino)-tetralin $(5,7)$.

The original synthesis of $\left[^{11} \mathrm{C}\right] \mathrm{MABV}$ involved direct ${ }^{11} \mathrm{C}$-methyl iodide methylation of alkanesulfonate salts of aminobenzovesamicol (ABV) $(5,8)$, but the relatively weak nucleophilicity of the aniline nitrogen required forcing conditions (115$\left.125^{\circ}, 15 \mathrm{~min}, \mathrm{DMF}\right)$ to speed the reaction. Side reactions and loss of $\left[{ }^{11} \mathrm{C}\right] \mathrm{methyl}$ iodide by volatilization occurred at these high temperatures which considerably reduced 
overall yields. Therefore, another route to MABV was sought which would be suitable for production of clinical scale batches $(50-200 \mathrm{mCi})$ of this promising tracer. This report details an original two step synthesis of $\left[{ }^{11} \mathrm{C}\right] \mathrm{MABV}$ using the tert-butoxycarbonyl (BOC) protecting group to activate the aniline nitrogen toward methylation under basic conditions, after which the "activating" group is removed by acid treatment.<smiles>COC(=O)Nc1cccc2c1CC(N1CCC(c3ccccc3)CC1)C(O)C2</smiles>

\section{RESULTS AND DISCUSSION}

$\mathrm{N}-\left[{ }^{11} \mathrm{C}\right]$ methylation of secondary amides with $\left[{ }^{11} \mathrm{C}\right]$ methyl iodide under basic conditions is a facile reaction that has been utilized for labeling of methyl spiperone (9) I'K11195 (10), and RO151788 (11). Benzanilides are readily $\mathrm{N}$-alkylated in the presence of $\mathrm{NaOH}$ and tetraalkylammonium phase transfer calalysts under conditions which favor the formation of the anilide anion (12). Thus it was reasoned that an amide derivative of $A B V$ could be methylated under similar conditions. Initial methylation experiments with $\mathrm{N}$-acetyl-ABV and tetrabutylammonium hydroxide (TBAOH) showed a very quick reaction of this analog with methyl iodide at room temperature, but deacetylation of the intermediate to MABV proved too slow for the carbon-11 time frame. Therefore the more easily cleaved BOC derivative was examined. HPLC monitoring of model reactions of $\mathrm{BOC}-\mathrm{ABV}$ with a limiting quantity of methyl iodide showed methylation to be complete within 1-5 min at room temperature in several solvents including DMF, $\mathrm{CH}_{3} \mathrm{CN}, \mathrm{CH}_{2} \mathrm{Cl}_{2}$, and THF. Other acyl derivatives including benzyloxycarbonyl and ethoxycarbonyl were found to similarly activate the aniline nitrogen of ABV toward methylation (data not shown). It is noteworthy that protecting group bulk seemed to have no adverse effect on methylation yields.

The anion of BOC-ABV appeared to form quickly after addition of TBAOH, judging from the development of a yellow color to the solution that could be discharged by adding excess methyl iodide or acid. Efficient and rapid methylation of BOC-ABV occurred with $0.5-2$ stoichiometric equivalents of this base relative to 
precursor. BOC-ABV/ TBAOH mixtures in THF remained stable and reactive toward methyl iodide for at least $10 \mathrm{~min}$ at room temperature according to HPLC monitoring of "cold" reactions. Nevertheless, as a general precation in radiosynthesis, the base was added just before the start and the BOC-ABV/ TBAOH solution was kept cold until $\left[{ }^{11} \mathrm{C}\right]$ methyl iodide addition was completed.

Following methylation, the $\mathrm{BOC}$ group was removed in $3 \mathrm{~N} \mathrm{HCl}$. In model reactions, cleavage was essentially complete within 1 minute at room temperature, but during actual radiosynthesis some spattering of labeled intermediate on the vessel walls from the passage of $\left.{ }^{11} \mathrm{C}\right]$ methyl iodide usually occurred. Therefore, to insure thorough acid contact for BOC cleavage the solution was heated and agitated by bubbling carrier gas through the solution during this stage.

Table. $\left[{ }^{11} \mathrm{C}\right] \mathrm{MABV}$ Production Data

\begin{tabular}{cc} 
Time of synthesis & $33-45 \mathrm{~min}$ \\
Radiochemical yield from target ${ }^{11} \mathrm{C}$ (corr.) & $30-70 \%$ \\
Yield (e.o.s., $15 \mathrm{~min} / 20 \mu \mathrm{A})$ & $70-230 \mathrm{mCi}$ \\
Radiochemical purity & $>98 \%$ \\
Chemical purity & $>90 \%$ \\
Specific activity (e.o.s.) & $0.5-1.5 \mathrm{Ci} / \mu \mathrm{mol}$ \\
\hline
\end{tabular}

Production data for 12 radiosyntheses are summarized in the Table. The overall radiochemical yield range is broad because it reflects the efficiencies of all steps of the synthesis, from in-target formation of and trapping of ${ }^{11} \mathrm{CO}_{2}$, to final product isolation. Rapid semi-preparative normal phase HPLC system completely separated [11C]MABV from the large excess of pharmacologically active ABV (3a); no traces of the latter compound were ever detectable in the final product solution by analytical HPLC. The principal impurities encountered were small amounts of BOC-ABV and BOC$\left[{ }^{11} \mathrm{C}\right] \mathrm{MABV}$. Under normal cleavage and purification conditions the combined amount of these compounds did not exceed $10 \%$ of the mass of MABV in the final product solution. BOC-ABV and BOC-MABV are estimated to be an order of magnitude less pharmacologically active than MABV based upon their toxicities in mice (Mulholland et al., unreported results). 


\section{CONCLUSIONS}

The traditional role of protecting groups in radiosynthesis is to mask the reactivity of competing functional groups toward unintended labeling or side reactions. In this work a "protecting" group has been used instead to selectively enhance the reactivity of the desired position. An efficient clinical scale synthesis of the cholinergic tracer $\left[{ }^{1} \mathrm{C}\right] \mathrm{MABV}$ has been developed by taking advantage of the fact that under mild basic conditions acyl derivatives of $\mathrm{ABV}$ methylate at the aniline position much faster than $\mathrm{ABV}$ itself. Competing methylation at the piperidine nitrogen was insignificant, and the activating effects on the aniline nitrogen appeared to be independent of acyl group bulk. The high yields and flexibility in the choice of reaction solvent seen with the present example indicate this general approach may be useful for labeling of other aniline-containing compounds of interest.

\section{EXPERIMENTAL}

${ }^{1} \mathrm{H}$ NMR spectra were obtained in $\mathrm{CDCl}_{3}$ on a Bruker $360-\mathrm{MHz}$ NMR spectrometer and are reported in parts per million downfield from tetramethylsilane. ${ }^{13} \mathrm{C}$ NMR spectra were measured at $90.56 \mathrm{MHz}$. Mass spectra were obtained on a Finnigan $4021 \mathrm{GC} / \mathrm{MS}$ system in the electron impact (EI) ionization mode. Molecular masses are given in atomic mass units (amu), followed by percent intensity relative to the most abundant ion. Elemental analysis was carried out by Spang Microanalytical Laboratory, Eagle Harbor, MI. Melting points were determined on a MEL-TEMP and are uncorrected. Flash chromatography utilized Merck 230-400 mesh silica gel. Thin-layer chromatography (TLC) used Analtech $0.25 \mathrm{~mm}$ plates with fluorescent background. THF was distilled from sodium-benzophenone ketyl immediately before use in radiosynthesis. TBAOH (1M, in methanol) was obtained from Aldrich. Carbon-11 isotope in the form of $\mathrm{CO}_{2}$ was produced by bombarding high purity nitrogen gas in an aluminum target with $17 \mathrm{MeV}$ protons $(20 \mu \mathrm{A})$. Direct measurement of trapped $\left[{ }^{11} \mathrm{C}\right] \mathrm{CO}_{2}$ in the synthesis apparatus was impractical, so for the purposes of calculating overall radiochemical yields, starting activity was estimated from previously determined standard curves of ${ }^{11} \mathrm{C}$ production values vs. irradiation time with this target. ${ }^{11} \mathrm{C}$ production from the target is approximately equal to theoretical thick target values calculated from cross section data (13). $\left[{ }^{11} \mathrm{C}\right] \mathrm{Methyl}$ iodide was produced through

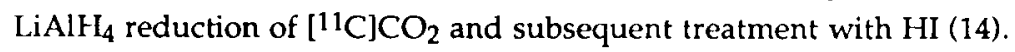

Racemic ABV and N-acetyl-ABV were prepared by published procedures (3a). The enantiomers of $\mathrm{ABV}$ were resolved by flash chromatography of the diastereomeric N,O-bis-(-)- $\alpha$-methoxy- $\alpha$-trifluoromethylphenylacetyl (MTPA) derivatives (15), followed by cleavage of the MPTA groups (16). Specific rotations of (-)- and (t)-ABV were $[\alpha]^{23} \mathrm{D}=-58.1^{\circ}(\mathrm{c}=1.6, \mathrm{EtOH})$ and $[\alpha]^{23} \mathrm{D}=+54.7^{\circ}(\mathrm{c}=1.5, \mathrm{E} \mathrm{OH})$, respectively. 
Authentic MABV was synthesized through $\mathrm{LiAlH}_{4}$ reduction of the $\mathrm{N}$ benzyloxycarbonyl derivative of (-)-ABV ((-)-(2R,3R)-trans-5-amino-2-hydroxy-3-(4phenylpiperidino)tetralin).

N-Benzyloxycarbonyl-ABV (Benzyl-(-)-(2R,3R)-trans-2-hydroxy-3-(4-phenylpiperidino)-5-tetralinyl carbamate). Benzyl chloroformate $(94 \mathrm{mg}, 0.55 \mathrm{mmol}$ ) and $\mathrm{Na}_{2} \mathrm{CO}_{3}$ (180 $\mathrm{mg}, 1.7 \mathrm{mmol}$ ) were added sequentially to a two phase solution of (-)-ABV (137 mg, $0.425 \mathrm{mmol})$ in $\mathrm{H}_{2} \mathrm{O}$ : THF: $\mathrm{Et}_{2} \mathrm{O}(30 \mathrm{~mL}: 20 \mathrm{~mL}: 20 \mathrm{~mL})$. The reaction mixture was stirred overnight at room temperature and poured into ethyl acetate $(30 \mathrm{~mL})$. The organic layer was separated, and the aqueous layer was extracted with ethyl acetate ( $2 \mathrm{x}$ $30 \mathrm{~mL}$ ). The combined organic extracts were washed with saturated $\mathrm{NaCl}$ solution, dried over anhydrous $\mathrm{Na}_{2} \mathrm{SO}_{4}$ and concentrated under reduced pressure. The crude product was flash chromatographed on silica, eluting with 40:60 ethyl acetate: hexane, to afford $171 \mathrm{mg}(88 \%)$ of $\mathrm{N}$-benzyloxycarbonyl-ABV as a white solid, m.p. $76-78^{\circ} \mathrm{C} .{ }^{1} \mathrm{H}$ NMR $81.69 \sim 1.97(\mathrm{~m}, 4 \mathrm{H}), 2.39(\mathrm{t}, 1 \mathrm{H}, \mathrm{J}=11.1 \mathrm{~Hz}) 2.52 \sim 2.62(\mathrm{~m}, 2 \mathrm{H}), 2.67 \sim 2.97(\mathrm{~m}, 6 \mathrm{H})$, 3.33(dd, $1 \mathrm{H}, \mathrm{J}=16.2,5.6 \mathrm{~Hz}$ ), 3.84(ddd, $1 \mathrm{H}, \mathrm{J}=16.2,10.3,5.6 \mathrm{~Hz}$ ), 5.23(s, 2H), 6.39(br.s, $1 \mathrm{H}$, $\mathrm{NH}), 6.93(\mathrm{~d}, 1 \mathrm{H}, \mathrm{J}=7.7 \mathrm{~Hz}), 7.14-7.60(\mathrm{~m}, 12 \mathrm{H}) ; \mathrm{MS}(\mathrm{EI}, 70 \mathrm{eV}) \mathrm{m} / \mathrm{z}$ (relative intensity): 456(65.5), 394(19.0), 348(81.2), 174(100.0), 160(39.7), 91(67.3); High-resolution MS (EI, 70 eV), calcd. for $\mathrm{C}_{29} \mathrm{H}_{32} \mathrm{~N}_{2} \mathrm{O}_{3}$ : 456.2413, Found: 456.2417; Anal. Calcd for $\mathrm{C}_{29} \mathrm{H}_{32} \mathrm{~N}_{2} \mathrm{O}_{3}$ : C: 76.29; H: 7.06; N: 6.14. Found: C: 76.31; H: 7.19; N: 6.21.

MABV ((-)-(2R,3R)-trans-5-( $N$-methylamino)-2-hydroxy-3-(4-phenylpiperidino)tetralin). $\mathrm{LiAlH}_{4}\left(0.75 \mathrm{~mL}\right.$ of $1.0 \mathrm{M}$ in $\left.\mathrm{Et}_{2} \mathrm{O}, 0.75 \mathrm{mmol}\right)$ was added dropwise to a solution of N-benzyloxycarbonyl-ABV (171 mg, $0.375 \mathrm{mmol}$ ) in dry THF (15 mL). The reaction mixture was refluxed with stirring for 5 hours and poured into $2 \mathrm{~N} \mathrm{NaOH}$ solution $(30 \mathrm{~mL})$. The aqueous layer was extracted with ether $(3 \times 30 \mathrm{~mL})$, dried over anhydrous $\mathrm{Na}_{2} \mathrm{SO}_{4}$ and concentrated under reduced pressure. The crude product was flash chromatographed on silica, eluting with 30:70 ethyl acetate/hexane to afford 107 $\mathrm{mg}(85 \%)$ of MABV as a white solid. m.p. $160^{\circ} \mathrm{C} ;{ }^{1} \mathrm{H}$ NMR $\delta 1.72 \sim 1.96(\mathrm{~m}, 4 \mathrm{H}), 2.39-$ $3.00(\mathrm{~m}, 12 \mathrm{H}), 3.25(\mathrm{dd}, 1 \mathrm{H}, \mathrm{J}=1.60,5.5 \mathrm{~Hz}) 3.52(\mathrm{br} . \mathrm{s}, 1 \mathrm{H}, \mathrm{NH}) 3.86(\mathrm{ddd}, 1 \mathrm{H}, \mathrm{J}=16.0,10.5,5.5$ $\mathrm{Hz}) 4.30(\mathrm{br} . \mathrm{s}, 1 \mathrm{H}, \mathrm{OH}) 6.49(\mathrm{~d}, 1 \mathrm{H}, \mathrm{J}=7.7 \mathrm{~Hz}) 6.56(\mathrm{~d}, 1 \mathrm{H}, \mathrm{J}=7.7 \mathrm{~Hz}), 7.12(\mathrm{t}, 1 \mathrm{H}, 7.7 \mathrm{~Hz}) 7.19-$ $7.35(\mathrm{~m}, 5 \mathrm{H}) ;{ }^{13} \mathrm{C} \mathrm{NMR}\left(\mathrm{CDCl}_{3}\right): \delta 20.54,30.8533 .92,34.40,38.28,43.01,45.04,53.53,65.24$, $66.78,107.03,118.27,118.98,126.25,126.80,127.14,128.47,134.35,146.03,147.02$; MS (EI, 70 eV) $\mathrm{m} / \mathrm{z}$ (relative intensity): $336\left(\mathrm{M}^{+}, 53.7\right), 318(3.0), 203(4.4), 176(100.0), 158(61.7)$, 144(20.4); High-resolution MS (EI, 70eV) calcd. for $\mathrm{C}_{22} \mathrm{H}_{28} \mathrm{~N}_{2} \mathrm{O}: 336.2202$, Found: 336.2198; Anal. Calcd for $\mathrm{C}_{22} \mathrm{H}_{28} \mathrm{~N}_{2} \mathrm{O}: \mathrm{C}: 78.53, \mathrm{H}: 8.39, \mathrm{~N}: 8.33$. Found: C: 78.47; H: 8.31, N: 8.25 .

BOC-ABV (tert-Butyl-(-)-(2R,3R)-trans-2-hydroxy-3-(4-phenylpiperidino)-5tetralinyl carbamate). Di-t-butyl dicarbonate $(73 \mathrm{mg}, 0.334 \mathrm{mmol}$ ) was added to a solution of (-)-ABV (49 $\mathrm{mg}, 0.152 \mathrm{mmol}$ ) in $\mathrm{EtOH}(2 \mathrm{~mL}), \mathrm{CHCl}_{3}(1 \mathrm{~mL})$ and triethylamine $(0.5 \mathrm{~mL})$ at room temperature. The resulting solution was stirred for 18 hours and concentrated under reduced pressure. The residue was purified by flash chromatography on silica, eluting with 30:70 ethyl acetate/hexane, to afford $58 \mathrm{mg}$ (90\%) of BOC-ABV as a white solid, m.p. $145^{\circ} \mathrm{C} ;{ }^{1} \mathrm{H}$ NMR: $\delta 1.55(\mathrm{~s}, 9 \mathrm{H}), 1.73-1.97(\mathrm{~m}, 4 \mathrm{H})$, $2.47(\mathrm{td}, 1 \mathrm{H}, \mathrm{J}=11.3,2.0 \mathrm{~Hz}), 2.54-2.64(\mathrm{~m}, 2 \mathrm{H}), 2.78-3.00(\mathrm{~m}, 6 \mathrm{H}), 3.30(\mathrm{dd}, 1 \mathrm{H}, \mathrm{J}=16.0,5.6 \mathrm{~Hz})$, 
3.85(ddd, $1 \mathrm{H}, \mathrm{J}=14.7,10.2,5.6 \mathrm{~Hz}$ ), 6.16(br.s, $1 \mathrm{H}, \mathrm{NH}$ ), 6.89(d, 1H, J=7.5 Hz), 7.15(t, 1H, J=7.5 $\mathrm{Hz}), 7.19-7.36(\mathrm{~m}, 5 \mathrm{H}), 7.57(\mathrm{~d}, 1 \mathrm{H}, \mathrm{J}=7.5 \mathrm{~Hz}) ; \mathrm{MS}(\mathrm{EI}, 70 \mathrm{eV}), \mathrm{m} / \mathrm{z}$ (relative intensity): 422( $\left.\mathrm{M}^{+}, 15.4\right), 366(5.8), 205(18.8), 188(8.9), 174(100), 160(71.6), 144(24), 130(31.6)$; High resolution MS (EI,70 eV0, calcd. for $\mathrm{C}_{26} \mathrm{H}_{34} \mathrm{~N}_{2} \mathrm{O}_{3}$ : 422.2569. Found: 422.2575; Anal. calcd. for $\mathrm{C}_{26} \mathrm{H}_{34} \mathrm{~N}_{2} \mathrm{O}_{3}: \mathrm{C}=73.90, \mathrm{H}=8.11, \mathrm{~N}=6.63$. Found: $\mathrm{C}=73.67, \mathrm{H}=7.99, \mathrm{~N}=6.70$.

Crystalline BOC-ABV and stock solutions in THF $(6.7 \mathrm{mg} / \mathrm{mL})$ were indefinitely stable at $-20^{\circ}$ over Drierite, but there were indications of slow decomposition (m.p. depression, TLC changes) over a several week period when the solid was stored at room temperature.

[11C]MABV ((-)-(2R,3R)-trans-5-(N-[11C]methylamino)-2-hydroxy-3-(4-phenylpiperidino)-tetralin ). [11 C]Methyl iodide (15), in a $30-50 \mathrm{~mL} / \mathrm{min} \mathrm{N}_{2}$ carrier stream, was passed into a $-30^{\circ} \mathrm{C}$ solution of BOC-ABV $(1 \mathrm{mg}, 2.4 \mu \mathrm{mol})$ and TBAH $(2 \mu \mathrm{L}$ of a $1 \mathrm{M}$ methanolic solution, $2 \mu \mathrm{mol}$ ) in $150 \mu \mathrm{L}$ of dry THF. After accumulation of radioactivity in the solution had peaked, the conical reaction vessel was sealed and warmed to $60^{\circ}$ for $1 \mathrm{~min}$ by means of a hot air gun. The heat was removed briefly while $150 \mu \mathrm{L}$ of $6 \mathrm{~N}$ methanolic $\mathrm{HCl}$ was added and then the reaction was returned to $60^{\circ}$ for an additional minute. Carrier gas was passed through the solution at this point to throughly agitate it. The reaction solution was next made basic with $1 \mathrm{M} \mathrm{NH}$, and the crude product was separated from water soluble materials by solid phase extraction using a $300 \mathrm{mg} \mathrm{C}-18$ silica (PrepSep, Fisher Scientific) column. The crude $\left[{ }^{11} \mathrm{C}\right] \mathrm{MABV}$ was then purified with a 5 micron normal phase HPLC column $(1 \times 15 \mathrm{~cm} \mathrm{A/CN}, E S$ Industries $)$ and a nonaqueous solvent system of 9:1 hexane: isopropanol at flow rate of $4 \mathrm{~mL} / \mathrm{min}$. The [11 C]MABV product eluted as a sharp peak at $7.5 \mathrm{~min}$. Retention times of other compounds of concern in this preparative system were: $A B V: 11 \mathrm{~min}, \mathrm{BOC}-\mathrm{ABV}: 8.3$ min, and BOC-MABV: $5.5 \mathrm{~min}$. After evaporation of the product fraction, [11 C]MABV was formulated in sterile saline containing $10 \%$ ethanol. Samples of the final solution were checked for carrier mass and radiochemical purity by analytical reverse-phase IPLC with serial UV (220 nm, Hitachi L4000) and radioactivity (CsF, Beckman 170) flow detectors. The analytical system consisted of a Regis $4.6 \times 250 \mathrm{~mm} 5$ micron C-18 column with a solvent mixture of 3: $1: 1 \mathrm{CH}_{3} \mathrm{CN}: \mathrm{MeOH}: 0.02 \mathrm{M} \mathrm{KHPO}_{4}^{-}(\mathrm{pH}$ 6.7). Capacity factors $\left(k^{\prime}\right)$ in this system were: $\mathrm{k}_{\mathrm{ABV}}^{\prime}$ : $1.76, \mathrm{k}_{\mathrm{MABV}}^{\prime}: 3.20, \mathrm{k}_{\mathrm{BOC}-\mathrm{ABV}}^{\prime}$ : 3.80, and $\mathrm{k}_{\mathrm{BOC}-\mathrm{MABV}}$ : 4.70 The mass quantification sensitivity limit of this system for $\mathrm{MABV}$ and $\mathrm{ABV}$, determined from standard injections in saline/ $10 \% \mathrm{EtOH}$, was approximately $10 \mathrm{ng} / 25 \mu \mathrm{L}$ of sample volume. Sensitivitity for BOC-ABV was slightly greater.

\section{ACKNOWLEDGEMENTS}

The authors are grateful for the helpful discussions and support of this work by Drs. Michael R. Kilbourn, Donald M. Wieland and David E. Kuhl. This work was supported by the following sources: National Institutes of Health grants 5 RO1 NS24896, 2 RO1 NS25656, 2 PO1 NS15655, and Department of Energy grant DE-02-87ER60528. 


\section{REFERENCES}

1. Marshall I.G., Parsons S. M. TINS 10, 174, (1987).

2. a. Marien, M. R., Parsons S. M., Altar C. A. Proc. Natl. Acad Sci. U.S.A. 84, 867, (1987). b. Hicks B. W., Rogers G. A., Parsons S. M. I. Neurochem. 57, 509-519, (1991).

3. a. Rogers G. A., Parsons S. M., Anderson D. C., Nilsson L. M., Bahr B. A., Kornreich W. D., Kaufman R., Jacobs R. S., Kirtman B. I. Med. Chem. 32, 1217-1230, (1989). b. Rogers G. A., Parsons S. M. NeuroReport 1, 11-14, (1990).

4. Jung Y.-W., Van Dort M. E., Gildersleeve D. L., Wieland D. M. I. Med. Chem. 33, 2065-2068, (1990).

5. Kilbourn M. R., Jung Y.-W., Haka M.S., Gildersleeve D. L., Kuhl D. E., Wieland D. M. Life Sci. 47, 1955-1963, (1990).

6. Mulholland G. K., Buck F., Sherman P. S., Pisani T. L., Jung Y-W., Frey K. A., Kuhl, D. E., Kilbourn M. R. J. Nucl. Med. 32, P994, (1991).

7. Jung Y-W., Mulholland G. K., Sherman P. S., Pisani T. L., Kilbourn M. R., Hutchins G. D., Wieland D. M. I. Nucl. Med. 32, P974, (1991).

8. Mulholland G. K., Jung Y-W., Haka M. S., Gilderslecve D., Van Dort M., Wieland D. M., Kilbourn M. R. J. Lab. Compd. Radiopharm. 30, P416, (1991).

9. Dannals R. F., Ravert H. T., Wilson A. A., Wagner H. N. Jr. In J. Appl Radiat. Isot. 37, 433-434, (1986).

10. Camsonne R., Crouzel C., Comar D., Maiziere M., Prenant C., Sastre J., Moulin M. A. J. Lab. Compd. Radiopharm. 31, 985-991, (1984).

11. Ehrin E., Johnstrom P., Stone-Elander S., et al., In Dahlbom R., Nilsson J.L.G.(eds). 8th International Symposium on Medicinal Chemisry, Uppsala Sweden, 1984, Vol 2, Swedish Pharmaceutical Press: Stockholm, pp 284-286, (1985).

12. Ayyangar N. R., Choudhary A. R., Kalkote U. R., Natu A. A. Syn. Comm. 18, 2011-2016 (1988). Kalkote U. R., Choudhary A. R., Natu A. A. , Lahoti R.J., Ayyangar N. R. ibid., 21, 1889-1900 (1988).

13. Hugel E.A. Doctoral Dissertation thesis. University of Michigan (1988).

14. Crouzel C., Langstrom B., Pike V. W., Coenen H. H. Appl. Radiat. Isot. 38, 601-603, (1987).

15. Dale J. A., Dull D. L., Mosher H. S. J. Org. Chem. 34, 2543, (1969).

16. Jung $\mathrm{Y}-\mathrm{W}$., et al., in preparation. 